\title{
HUBUNGAN ANTARA KOMPETENSI PROFESIONAL DAN MOTIVASI BERPRESTASI DENGAN KREATIVITAS KERJA GURU
}

\author{
Sugiarti ${ }^{1}$, Rita Retnowati ${ }^{2}$, Eka Suhardi ${ }^{2}$ \\ ${ }^{1}$ Guru SD Teluk Jambe, Karawang, Jawa Barat \\ ${ }^{2}$ Program Pascasarjana Universitas Pakuan, \\ Email: pasca@unpak.ac.id
}

\begin{abstract}
The teacher's creativity is a behavior that shows acceptance and implementation of performance changes either in the form of ideas, processes or products that have added values to achieve the goals of quality education. This study is a correlation research consisting of two independent variables and one dependent variable, namely the teacher's professional commpetence and achievement motivation with teacher's working creativity. This research was carried out in 20 of State Elementary School in North Telukjambe Region of Karawang district in west java with total population are 198 state teacher, using survey method. The total sample are 133. The sampling technique is the proportional random sampling. The data were analyzed using correlational and simple linier regressional statistical technique. The hypothesis were tested at the 0.05 significance level. The research result shows that 1) there is positive correlation between a teacher's professional commpetence $(X 1)$ with teacher's creativity $(Y)$ with an rxly $=0.417$ with regression equation $\hat{Y}=133.5+1.186 \mathrm{X1}, 2)$ there is positive correlation between teacher' s creativity $(X 2)$ with teacher' $s$ working creativity with an rx $2 y=0.456$ with regression equation $\hat{Y}=$ $51.91+0.753 X 2,3)$ there is positive correlation between a teacher's professional commpetence and achievement motivation together with teacher' $s$ creativity with an rx $1 x 2 y$ $=0.554$ with regression equation $\hat{Y}=49.420+0.919 X 1+0.620 X 2$. The implications of this research is to increase of the creativity of teacher that can be done by increasing indicators of teacher's professional commpetence and achievement motivation variables, either individually or collectively.
\end{abstract}

Keyword: Teacher's Creativity, Professional Commpetence, Achievement Motivation

\begin{abstract}
ABSTRAK
Penelitian korelasional yang terdiri atas dua variabel bebas yaitu kompetensi profesional guru dan motivasi berprestasi guru dan variabel terikat yaitu kreativitas guru. Keinovatifan adalah prilaku yang menunjukan penerimaan dan implementasi terhadap perubahan kinerja baik berupa ide, proses ataupun produk yang memiliki nilai tambah untuk mencapai tujuan pendidikan yang berkualitas Penelitian ini dilaksanakan di 20 SDN pada guru-guru yang Berstatus PNS di Kec. Karawang Timur, Kabupaten Karawang sebanyak 198 guru pada tahun 2017 dengan menggunakan metode survei. Jumlah sampel sebanyak 133 responden dengan teknik penarikan sampel menggunakan teknik proportional random sampling. Teknik analisis data menggunakan teknik statistik korelasi dan regresi linier sederhana serta korelasi dan regresi ganda. Pengujian hipotesis dilakukan pada taraf signifikansi 0,05. Hasil penelitian menunjukan bahwa: 1) Terdapat hubungan positif yang sangat signifikan antara kompetensi profesional guru (X1) dengan kreativitas guru $(\mathrm{Y})$ dengan $\mathrm{rx} 1 \mathrm{y}=0,417$ dengan persamaan regresi $\hat{Y}=133,5+1,186 \mathrm{X} 1,2)$ Terdapat hubungan positif yang signifikan antara motivasi
\end{abstract}


berprestasi guru (X2) dengan kreativitas guru (Y) dengan rx2y $=0,456$ dengan persamaan regresi $\hat{Y}=51,91+0,753 \mathrm{X} 2$ dan 3 ) terdapat hubungan positif yang signifikan antara kompetensi profesional guru dan motivasi berprestasi guru secara bersama-sama dengan kreativitas guru dengan $\mathrm{rx} 1 \mathrm{x} 2 \mathrm{y}=0,554$ dengan persamaan regresi $\hat{\mathrm{Y}}=49,420+0,919 \mathrm{X} 1+$ 0,620X2. Implikasi dari hasil penelitian ini adalah peningkatan kreativitas guru dapat dilakukan dengan cara meningkatkan indikator-indikator variabel kompetensi profesional guru dan motivasi berprestasi guru, baik secara sendiri-sendiri maupun bersamaan.

Kata kunci: Kreativitas Guru, Kompetensi Profesional, Motivasi Berprestasi

\section{PENDAHULUAN}

Problematika dunia pendidikan di Indonesia sering dianggap hal yang sangat pelik dan komplek, terkadang sulit untuk melihat titik kulminasi persoalan tersebut secara jernih. Namun berbagai pihak, seakan tak pernah berhenti memberi sumbang saran terbaiknya, agar pendidikan di Indonesia terus mengalami peningkatan kualitas maupun kuantitas. Meningkatkan kualitas proses dan hasil pembelajaran harus dimulai dari guru itu sendiri, sebab guru merupakan garda terdepan yang berhubungan langsung dengan siswa. Syarat utama guru untuk dapat mengajar dengan baik adalah guru yang memiliki kompetensi pedagogik dan kompetensi profesional. Guru yang tidak kompeten tentu tidak akan dapat menghasilkan siswa yang baik secara paripurna.

Tugas mulia di atas merupakan tanggung jawab bersama dan harus disukseskan oleh semua pihak terkait antara sekolah atau lembaga pendidikan, pemerintah dan keluarga peserta didik itu sendiri. Semua harus berperan aktif dan saling mendukung. Sekolah dan guru harus terus aktif untuk meningkatkan kompetensinya terutama kompetensi profesional, dan tiada henti meningkatkan kreativitasnya dalam menentukan strategi pembelajaran yang lebih aktif kreatif dan inovatif sehingga pembelajaran menyenangkan siswa untuk mendorong semangat dan kemampuan siswa dalam pembelajaran. Sementara peran keluarga harus memberikan dukungan penuh dalam menciptakan kondusivitas proses pembelajaran baik di sekolah maupun di rumah.

\section{Kreativitas Guru}

Menurut Gibson (2006:119-120) Kreativitas adalah perwujudan idea-idea (gagasan) yang unggul dalam bentuk peluang atau produk usaha. Faktor-faktornya : a) keyakinan diri dalam menemukan pemecahan masalah, b) keberanian bertindak, c) kecerdikan mencari peluang atau cara baru, d) keterbukaan terhadap idea-idea orang lain. Seseorang yang kreatif memiliki keberanian dalam bertindak serta mampu mewujudkan suatu hasil karya dari ide-ide yang diperoleh tapi tidak menutup kemungkinan untuk terbuka terhadap ide-ide baru yang lain untuk dijadikan peluang-peluang atau cara-cara baru yang lebih baik.

Menurut Greenberg (2008:561) kreativitas adalah suatu proses yang dilakukan individu atau kelompok dalam menghasilkan karya atau ide yang lebih berguna. Greenberg menyatakan pula bahwa komponen kreativitas dalam individu atau kelompok meliputi tiga dasar hubungan utama yaitu: hubungan antara kesesuaian hasil dengan kemampuan, kesesuaian kreativitas dengan kemampuan serta dorongan motivasi intrinsik.

Berdasarkan kajian teori di atas dapat disimpulkan bahwa kreatifitas guru adalah tindakan seorang guru untuk menciptakan ide-ide baru, suatu gagasan baru maupun karya nyata yang relatif berbeda dengan apa yang sebelumnya dan menjadi daya pendorong dalam rangkaian kegiatan pembelajaran. 


\section{Kompetensi Profesional}

Sejumlah pakar besar di bidang sumber daya manusia yang tergabung dalam kelompok Hay-McMer (dipelopori oleh Mc Clelland) dalam Prihadi (2004:9) menyepakati bahwa kompetensi adalah seperangkat pengetahuan, keterampilan dan sikap yang saling terikat mempengaruhi sebagian besar jabatan (peranan atau tanggung jawab), berkorelasi dengan kinerja pada jabatan tersebut, dan dapat diukur dengan standar-standar yang dapat diterima, serta dapat ditingkatkan melalui upaya-upaya pelatihan dan pengembangan.

Lepsinger dalam Prihadi (2004:11) menyatakan bahwa kompetensi dibangun di atas fondasi yang menggabungkan berbagai jenis keterampilan dan pengetahuan yang didapatkan melalui pembelajaran, usaha, dan pengalaman. Semua kemampuan bawaan dan yang diperoleh mnaifests dalam satu set perilaku tertentu.

Johnson dalam Sanjaya (2009: 79) menyatakan bahwa: "competency as rational performance which satisfactirily meets the objective for a desired condision". Menurutnya, kompetensi merupakan perilaku rasional guna mencapai tujuan yang dipersyaratkan sesuai dengan kondisi yang diharapkan. Dengan pengertian ini, suatu kompetensi ditunjukan oleh penampilan atau unjuk kerja yang dapat dipertanggungjawabkan dalam upaya mencapai tujuan.

Berdasarkan teori-teori di atas maka yang dimaksud dengan kompetensi profesional guru adalah seperangkat pengetahuan, keterampilan, dan perilaku yang harus dimiliki, dihayati, dan dikuasai oleh guru dalam melaksanakan tugas keprofesionalan.

\section{Motivasi Berprestasi}

Mc Clelland (Uno, 2016 : 47) menekankan pentingnya kebutuhan berprestasi, karena orang yang berhasil dalam bisnis dan industri adalah orang yang berhasil menyelesaikan segala sesuatu. Seiring dengan pendapat Nurul (2015:49) motivasi berprestasi diartikan sebagai dorongan mental yang dimiliki oleh seseorang dalam mencapai prestasi yang terbaik.

Studi yang dilakukan oleh Smith dan Cranny (Danim dan Suparno, 2009 : 36) memperlihatkan bahwa motivasi berprestasi berhubungan dengan tingkat pengorbanan seseorang dalam mencapai tujuan atau ekspektasi yang diharapkan. Semakin tinggi motivasi berprestasi seseorang, semakin besar ekspektasi yang mereka miliki, semakin tinggi pula pengorbanan yang mereka berikan. Salami (2008 : 31-38), mengemukakan bahwa Motivasi berprestasi adalah dorongan untuk bekerja dalam rangka mencapai suatu standar tinggi (standard of excellent) dan meraih keberhasilan dalam situasi persaingan. Sementara, McClelland (Siburian, 2013:255) mengemukakan bahwa motivasi berprestasi (need for achievement) merupakan hasrat untuk melampaui suatu standar yang ditetapkan, dan berjuang untuk meraih keberhasilan. dapat dikatakan bahwa terdapat beberapa aspek terkait dengan motivasi berprestasi antara lain ; berani menempuh resiko, hasrat memperoleh umpan balik atas kinerjanya, mencari kepuasan dengan berprestasi serta memikul tanggung jawab atas pekerjaannya.

Berdasarkan uraian teori-teori di atas dapat disimpulkan bahwa yang dimaksud dengan motivasi berprestasi adalah dorongan yang kuat dari seseorang untuk mencapai sesuatu yang telah menjadi tujuannya untuk menghasilkan karya yang unggul. Indikatornya yaitu: a. keinginan yang kuat, b. menyenangi pekerjaan, c. bekerja keras, d. pantang menyerah, dan e. bersaing yang sehat.

\section{METODE PENELITIAN}

Penelitian ini dilaksanakan di wilayah Kecamatan Telukjambe Timur Kabupaten Karawang Provinsi Jawa Barat yang berjumlah 26 sekolah. Unit analisis penelitian ini adalah guru SD Negeri se-Kecamatan Telukjambe Timur Kabupaten Karawang. 
Waktu penelitian rencananya akan dilaksanakan pada bulan Februari 2017 sampai dengan bulan April 2017 dengan jumlah guru kelas Sekolah dasar Negeri yang PNS (Pegawai Negeri Sipil) se-Kecamatan Telukjambe Timur Kabupaten Karawang.sebanyak $=198$ orang dengan jumlah responden 133 orang. Waktu pelaksanaan penelitian tidak mengganggu proses belajar mengajar disekolah yang bersangkutan. Dengan menggunakan instrumen yang telah memenuhi syarat (valid dan reliable) untuk dapat dijadikan alat pengumpul data, maka langkah selanjutnya adalah melakukan penelitian terhadap guru kelas SD Negeri yang PNS (Pegawai Negeri Sipil) se-Kecamatan Telukjambe Timur Kabupaten Karawang.

\section{HASIL PENELITIAN}

\section{Pengujian Persyaratan Analisis}

\section{Uji Normalitas}

a. Uji normalitas pada galat baku Data Kreativitas Guru (Y) atas Kompetensi Profesional Guru $\left(\mathbf{X}_{1}\right)$

Hasil perhitungan normalitas galat taksiran didapatkan nilai Lo maks $=0,0759$ sementara itu Ltabel $=0,0768$. Persyaratan normal adalah Lo maks $<$ Ltabel menunjukan bahwa galat baku taksiran data kreativitas guru atas kompetensi profesional guru berasal dari data yang berdistribusi normal.

\section{b. Uji normalitas galat baku Data Kreativitas Guru (Y) atas Motivasi Berprestasi $\left(\mathbf{X}_{2}\right)$ \\ Hasil perhitungan normalitas galat taksiran didapatkan nilai Lo maks $=0,0731$} sementara itu Ltabel $=0,0768$. Persyaratan normal adalah Lo maks < Ltabel menunjukan bahwa galat baku taksiran data kreativitas guru atas motivasi berprestasi guru berasal dari data yang berdistribusi normal.

\section{Uji Homogenitas}

a. Uji Homogenitas Kreativitas Guru atas Kompetensi Profesional Guru $\left(\mathbf{X}_{1}\right)$

Uji homogenitas data kreativitas guru atas kompetensi profesional guru diuji dengan menggunakan uji Barlett. Berdasarkan uji tersebut diperoleh nilai $\chi_{2}$ hitung $=82,218$ sedangkan $\chi 2$ tabel $=134,360$. Persyaratan homogen adalah $\chi 2$ hitung $<\chi 2$ tabel, kelompok data kreativitas guruatas kompetensi profesional guru berasal dari data yang homogen.

\section{b. Uji Homogenitas Kreavitas Guru (Y) atas Motivasi Berprestasi $\left(\mathrm{X}_{2}\right)$}

Uji homogenitas data kreativitas guru atas motivasi berprestasi guru diuji pula dengan yang sama yakni uji Barlett. Berdasarkan uji tersebut diperoleh nilai $\chi 2$ hitung $=71,802$ sedangkan $\chi 2$ tabel $=126,570$. Persyaratan homogen adalah $\chi 2$ hitung $<\chi 2$ tabel, , kelompok data kreativitas guru atas motivasi berprestasi guru berasal dari data yang homogen.

\section{Pengujian Hipotesis}

\section{Hubungan antara variabel Kompetensi Profesional Guru dengan Kreativitas Guru}

Analisis linier sederhana antara kompetensi profesional guru dengan kreativitas guru memiliki persamaan regresi $\hat{\mathrm{Y}}=133,5+1,186 \mathrm{X} 1$ dengan arah koefisien regresi sebesar 1,186 dan konstanta sebesar 133,5. Pengujian mengenai seberapa besar kebenaran hasil regresi tersebut, yang juga dimaksudkan untuk menguji hipotesis tentang adanya hubungan positif antara kompetensi profesional guru (X1) dengan kreativitas guru (Y), maka untuk keperluan itu diperlukan uji signifikansi dan linier terhadap persamaan regresi dengan menggunakan uji F. 
Perhitungan Analisis korelasi sederhana menghasilkan koefisien korelasi ry1 sebesar 0,417 dan koefisien determinasi ( $\mathrm{r} 2$ ) sebesar 0,174 yang artinya X1 memiliki kontribusi sebesar 17,404 \% terhadap peningkatan kreativitas guru. Hasil pengujian keberartian koefisien korelasi diperoleh thitung sebesar 6,373 yang lebih besar dari tabel sebesar 1,658. Berdasarkan data tersebut di atas maka hasil uji hipotesis kompetensi profesional guru (X1), dapat disimpulkan bahwa Ho ditolak, sedangkan $\mathrm{H} 1$ yang menyatakan terdapat hubungan positif antara X1 (kompetensi professional guru) dengan Y (kreativitas guru) diterima.

\section{Hubungan variabel Motivasi Berprestasi Guru dengan Kreativitas Guru}

Analisis linier sederhana antara motivasi berprestasi guru dengan kreativitas guru memiliki persamaan regresi $\hat{Y}=51,91+0,753 X 2$ dengan arah koefisien regresi sebesar 0,753 dan konstanta sebesar 51,910. Pengujian mengenai seberapa besar kebenaran hasil regresi tersebut, yang juga dimaksudkan untuk menguji hipotesis tentang adanya hubungan positif antara motivasi berprestasi guru (X2) dengan kreativitas guru (Y), maka untuk keperluan itu diperlukan uji signifikansi dan linier terhadap persamaan regresi dengan menggunakan uji $\mathrm{F}$.

Perhitungan Analisis korelasi sederhana menghasilkan koefisien korelasi ry2 sebesar 0,456 dan koefisien determinasi $\left(\mathrm{r}_{2}\right)$ sebesar 0,2086 yang artinya $\mathrm{X}_{2}$ memiliki kontribusi sebesar 20,860\% terhadap peningkatan kreativitas guru. Hasil pengujian keberartian koefisien korelasi diperoleh thitung sebesar 5,877 yang lebih besar dari tabel sebesar 1,658. Berdasarkan data tersebut di atas maka hasil uji hipotesis motivasi berprestasi guru ( $\left.\mathrm{X}_{2}\right)$, dapat disimpulkan bahwa $\mathrm{H}_{0}$ ditolak, sedangkan $\mathrm{H}_{1}$ yang menyatakan terdapat hubungan positif antara $\mathrm{X}_{2}$ (motivasi berprestasi guru ) dengan $\mathrm{Y}$ (kreativitas guru) diterima.

\section{Hubungan antara Kompetensi Profesional Guru $\left(X_{1}\right)$ dan Motivasi Berprestasi Guru $\left(\mathbf{X}_{2}\right)$ secara Bersama-sama dengan Kreativitas Guru (Y)}

\section{a. Uji Regresi Ganda}

Analisis regresi linier ganda antara kompetensi profesional guru dan motivasi berprestasi guru secara besama-sama dengan kreativitas guru ditampilkan dalam bentuk persamaan regresi sebagai berikut: $\hat{\mathrm{Y}}=49,420+0,919 \mathrm{X} 1+0,620 \mathrm{X} 2$ dengan arah koefisien regresi a1 sebesar 0,919, a2 sebesar 0,620 dan konstanta a0 sebesar 49,420. Untuk menguji hipotesis yang menyatakan bahwa terdapat hubungan positif antara kompetensi profesional guru (X1) dan motivasi berprestasi guru (X2) secara bersama-sama dengan kreativitas guru (Y), diperlukan uji signifikansi dan liniearitas terhadap persamaan regresi dengan menggunakan uji F.

Hasil perhitungan uji keberartian persamaan regresi linier ganda diperoleh Fhitung= 18,410 yang lebih besar dari $F_{\text {tabel }}=3,060$. Berdasarkan data ini dapat diambil kesimpulan bahwa $\mathrm{H}_{0}$ ditolak, artinya $\mathrm{H}_{1}$ yang menyatakan hubungan positif antara $\mathrm{X}_{1}$ (kompetensi profesional guru) dan $\mathrm{X}_{2}$ (motivasi berprestasi guru) secara bersama-sama dengan $\mathrm{Y}$ (kreativitas guru), diterima.

\section{b. Uji Korelasi Ganda}

Analisis korelasi ganda menghasilkan koefisien korelasi ry12 sebesar 0,554 dan koefisien determinasi $(\mathrm{R})$ sebesar $0,307 \times 100 \%=30,700 \%$. Hasil pengujian keberartian koefisien korelasi diperoleh $\mathrm{F}$ hitung sebesar 28,793 yang lebih besar dari Ftabel sebesar 3,060. Artinya hasil uji korelasi ganda sangat signifikan.

\section{Uji Korelasi Parsial}

Koefisien korelasi antara kompetensi profesional guru dengan kreativitas guru dikontrol oleh variabel motivasi berprestasi memiliki nilai ry12 sebesar 0,222. Pengujian tingkat 
signifikansi dari koefisien korelasi parsial yang dikontrol oleh variabel X2 dilakukan dengan uji t. Hasil perhitungan diperoleh thitung $=2,591$ yang lebih besar daripada ttabel $=1,960$, dengan demikian hubungan antara kompetensi profesional guru (X1) dengan kreativitas guru (Y) tetap signifikan meskipun dikontrol oleh variabel motivasi berprestasi atau variabel motivasi berprestasi (X2) tidak mempengaruhi secara signifikan terhadap hubungan antara kompetensi

Koefisien korelasi antara motivasi berprestasi dengan kreativitas guru dikontrol oleh variabel kompetensi profesional guru memiliki nilai ry21 sebesar 0,298. Pengujian tingkat signifikansi dari koefisien korelasi parsial yang dikontrol oleh variabel $\mathrm{X}_{1}$ dilakukan dengan uji t. Hasil perhitungan diperoleh thitung $=3,563$ yang lebih besar daripada tabel $=1,960$, dengan demikian hubungan antara motivasi berprestasi $\left(\mathrm{X}_{2}\right)$ dengan kreativitas guru (Y) tetap signifikan meskipun dikontrol oleh variabel kompetensi profesional guru atau variabel kompetensi professional guru $\left(\mathrm{X}_{1}\right)$ tidak mempengaruhi secara signifikan terhadap hubungan antara motivasi berprestasi $\left(\mathrm{X}_{2}\right)$ dengan kreativitas guru $(\mathrm{Y})$.

\section{PEMBAHASAN}

\section{Hubungan Variabel Kompetensi Profesional Guru (X1) dengan Variabel Kreativitas Guru (Y)}

Berdasarkan analisis persamaan regresi linier sederhana bentuk hubungan kompetensi profesional guru dengan kreativitas guru memiliki persamaan regresi $\hat{Y}=133,5+1,186 X_{1}$ dengan arah koefisien regresi sebesar 1,186 dan konstanta sebesar 133,5 dan Fhitung sebesar 27,603 yang lebih besar dari Ftabel sebesar 3,920 yang berati sangat signifikan. Sedangkan hasil uji linieritas untuk persamaan regresi 73 antara $\mathrm{X}_{1}$ dengan $\mathrm{Y}$ diperoleh Fhitung sebesar 1,258 yang lebih kecil dari Ftabel sebesar 1,630 yang berarti persamaan regresi merupakan persamaan linier. Perhitungan Analisis korelasi sederhana menghasilkan koefisien korelasi $\mathrm{r}_{\mathrm{y}}$ sebesar 00,417 dan koefisien determinasi ( $\left.\mathrm{r}_{2}\right)$ sebesar 0,1740 yang berarti bahwa variabel $\mathrm{X}_{1}$ memiliki kontribusi sebesar $17,400 \%$ terhadap peningkatan variabel Y. Hasil pengujian keberartian koefisien korelasi diperoleh diperoleh thitung sebesar 6,373 yang lebih besar dari tabel sebesar 1,658. Berdasarkan data hasil uji hipotesis kompetensi profesional guru $\left(\mathrm{X}_{1}\right)$ dengan kreativitas guru (Y), maka dapat disimpulkan bahwa $\mathrm{H}_{0}$ ditolak, berarti $\mathrm{H}_{1}$ yang menyatakan terdapat hubungan positif antara $\mathrm{X}_{1}$ (kompetensi profesional guru ) dengan $\mathrm{Y}$ (kreativitas guru) diterima.

Hasil penelitian yang relevan terdahulu telah membuktikan bahwa hubungan antara metakognisi dan motivasi berprestasi dengan kreativitas yang dilakukan oleh Kuntjojo dan Matulessy (2012:1). Kompetensi dalam pelaksanaanya menjelaskan apa yang dilakukan ditempat kerja. Johnson dalam Sanjaya (2009: 79) menyatakan bahwa kompetensi merupakan perilaku rasional guna mencapai tujuan yang dipersyaratkan sesuai dengan kondisi yang diharapkan. Dengan pengertian ini, suatu kompetensi ditunjukan oleh penampilan atau unjuk kerja yang dapat dipertanggungjawabkan dalam upaya mencapai tujuan.

Hal ini berarti semakin tinggi tingkat kompetensi profesional guru maka akan semakin tinggi pula tingkat kreativitas guru. Dengan demikian temuan fakta dan data dalam analisis penelitian ini semakin mendukung temuan-temuan terdahulu mengenai adanya hubungan positif antara kompetensi profesional guru dengan kreativitas guru.

\section{Hubungan Positif antara Motivasi Berprestasi Guru $\left(\mathrm{X}_{2}\right)$ dengan Kreativitas Guru (Y)}

Berdasarkan analisis persamaan regresi linier sederhana bentuk hubungan motivasi berprestasi guru dengan kreativitas guru memiliki persamaan regresi $\hat{Y}=51,91+0,753 X 2$ dengan arah koefisien regresi sebesar 0,753 dan konstanta sebesar 51,910 diperoleh Fhitung sebesar 34,548 yang lebih besar dari Ftabel sebesar 3,920 yang berati sangat signifikan. Sedangkan hasil uji linieritas untuk persamaan regresi antara X2 dengan Y diperoleh Fhitung 
sebesar 1,571 yang lebih kecil dari Ftabel sebesar 1,720 yang berarti persamaan regresi merupakan persamaan linier. Perhitungan Analisis korelasi sederhana menghasilkan koefisien korelasi ry2 sebesar ry2 sebesar 0,456 dan koefisien determinasi (r2) sebesar 0,2086 yang berarti bahwa variabel X2 memiliki kontribusi sebesar $20,860 \%$ terhadap peningkatan variabel Y. Hasil pengujian keberartian koefisien korelasi diperoleh diperoleh thitung sebesar 5,877 yang lebih besar dari ttabel sebesar 1,658.

Hasil penelitian yang relevan terdahulu karya Fina Rizqiyana (2013:1), telah membuktikan tentang Kompetensi Profesional Dan Kreativitas Guru dalam Pembelajaran Sejarah (Studi Korelasi Untuk memperoleh gelar Sarjana Pendidikan Fakultas Ilmu Sosial Universitas Negeri Semarang Korelasional Guru Sejarah SMA di Kabupaten Tegal) yang menyatakan bahwa: Berdasarkan hasil penelitian dan analisis data, diperoleh koefisien korelasi sebesar 0,699 dengan rtabel $=0,666$ sehingga terdapat hubungan yang positif. Hasil uji $\mathrm{t}$ atau secara parsial diperoleh thitung sebesar 2,128 dengan probabilitas $0,007<0,05$ maka dengan demikian Ha diterima yang berarti ada hubungan antara kompetensi profesional dan kreativitas guru dalam pembelajaran sejarah. Simpulan dari penelitian ini adalah kompetensi profesional berhubungan baik dengan kreativitas guru dalam pembelajaran sejarah dan semakin tinggi kompetensi profesional guru maka kreativitas guru pun semakin meningkat. Hal ini sesuai dengan teori yang dikemukakan Mangkunegara (2009: 22) yang menyatakan bahwa motivasi berprestasi selalu ditunjukkan dalam aktivitas kinerja yang dilakukan individu. Karakteristik individu yang mempunyai motivasi berprestasi tinggi antara lain memiliki tanggung jawab pribadi yang tinggi, memiliki program kerja berdasarkan rencana dan tujuan yang realistis serta berjuang merealisasikannya, kemampuan mengambil keputusan dan berani mengambil resiko yang dihadapi, melakukan pekerjaan yang berarti dan menyelesaikannya dengan hasil memuaskan dan mempunyai keinginan menjadi orang yang terkemuka yang menguasai bidang tertentu.

\section{Hubungan positif antara Kompetensi Profesional Guru dan Motivasi Berprestasi Sekolah secara Bersama-sama Kreativitas Guru.}

Analisis regresi linier ganda antara kompetensi profesional guru dan motivasi berprestasi guru secara besama-sama dengan kreativitas guru ditampilkan dalam bentuk persamaan regresi sebagai berikut: $\hat{\mathrm{Y}}=49,420+0,919 \mathrm{X}_{1}+0,620 \mathrm{X}_{2}$ dengan arah koefisien regresi a1 sebesar 0,919, a2 sebesar 0,620 dan konstanta a0 sebesar 49,420. Hasil perhitungan uji keberartian persamaan regresi linier ganda diperoleh Fhitung $=18,410$ yang lebih besar dari Ftabel $=3,060$.

Berdasarkan data ini dapat diambil kesimpulan bahwa $\mathrm{H}_{0}$ ditolak, artinya $\mathrm{H}_{1}$ yang menyatakan hubungan positif antara $\mathrm{X}_{1}$ (kompetensi profesional guru) dan $\mathrm{X}_{2}$ (motivasi berprestasi guru) secara bersama-sama dengan Y (kreativitas guru) diterima. Analisis korelasi ganda menghasilkan koefisien korelasi ry12 sebesar 0,554 dan koefisien determinasi (R) sebesar 0,307 sehingga kontribusi variabel $\mathrm{X}_{1}$ dan $\mathrm{X}_{2}$ dalam meningkatan variabel $\mathrm{Y}$ sebesar $30,700 \%$. Hasil pengujian keberartian koefisien korelasi diperoleh diperoleh $\mathrm{F}$ hitung sebesar 28,793 yang lebih besar dari Ftabel sebesar 3,060.

Dengan demikan apabila organisasi sekolah memiliki guru yang memiliki dan menguasai kompetensi profesional yang baik dan memiliki motivasi berprestasi yang terbina dengan baik dan diterapkan secara secara bersama-sama maka akan sanggup meningkatkan kreativitas guru di sekolah tersebut secara signifikan dan optimal.

\section{SIMPULAN}

Berdasarkan analisis terhadap data hasil penelitian dapat disimpulkan terdapat hubungan positif sangat signifikan antara kompetensi profesional guru dengan kreativitas guru, antara motivasi berprestasi dengan kreativitas guru, antara kompetensi profesional guru 
dan motivasi berprestasi secara bersama-sama dengan kreativitas guru. Berdasarkan hasil penelitian ini maka untuk meningkatkan kreativitas guru dapat dilakukan dengan meningkatkan kompetensi professional guru dan perbaikan pada motivasi berprestasi guru.

\section{DAFTAR PUSTAKA}

A. Nadler, David dan Edward E. Lawlar III. (1995). Motivation A. Diagnostic Approach. Dikutip tidak langsung oleh Stoner, Freeman, Gilbert, Management. New Jersey: Pientice-Hall, Inc.

Bisri, Hasan. (2008). Hubungan Antara Komunikasi Interpersonal dan MotivasiKerja dengan Kepuasan Kerja Guru. PPS UNPAK Bogor: Tesis.

Colquit dkk, Jason A, (2009). Organizational: Improving Performance and Commitment in the Workplace, New York: Mc Graw-Hill.

Danim, Sudarwan. (2004). Motivasi, Kepemimpinan dan Efektivitas Kelompok. Jakarta: PT. Rhineka Cipta.

Danim, Sudarwan dan Khairil.(2010). Profesi Kependidikan. Bandung: Alfabeta, 2010.

Fathoni, Abdurrahmat (2006). Manajemen Sumber Daya Manusia. Jakarta: PT Rineka Cipta.

Fina Rizqiyana, Kompetensi Profesional Dan Kreativitas Guru Dalam Pembelajaran Sejarah (Studi Korelasi Untuk memperoleh gelar Sarjana Pendidikan Fakultas Ilmu Sosial Universitas Negeri Semarang Korelasional Guru Sejarah SMA di Kabupaten Tegal),

Handoko, T, Hani. (2001). Manajemen Personalia \& Sumberdaya Manusia. Yogyakarta: BPFE Yogyakarta.

Hasibuan, Melayu, S.P.(2000). Manajemen Sumber Daya Manusia. Jakarta: Bumi Aksara, (2016). Organisasi dan Motivasi. Jakarta: Bumi Aksara.

Kuntjojo dan Andik Matulessy, Hubungan Antara Metakognisi Dan Motivasi Berprestasi Dengan Kreativitas, Jurnal Psikologi Persona Volume 01 omor 01 Juni 2012.

Mangkunegara, Anwar, Prabu. (2009). Manajemen Sumber Daya Manusia Perusahaan, Bandung: Remaja Rosdakarya.

-----------. (2003). Menjadi Kepala Sekolah Profesional. Bandung: PT. Remaja Rosdakarya.

Riduwan \& Engkos Achmad Kuncoro. (2008). Cara Menggunakan dan Memakai Analisis Jalur. Bandung: Alfabeta

Robert, Kreitner, \& Angelo K. (2005) Organizational Behaviour. Jakarta: Salemba Empat, 
Rohaeni, Dedeh. (2006). Hubungan antara Supervisi Kepala Sekolah dan Motivasi Berprestasi Guru dengan Kepuasan Kerja Guru, PPS UNPAK Bogor: Tesis.

Rue, Luslie W. And Lloyd L. Byiars, (2007). Supervision Key Link to Productivity, New York: Mc Graw-Hill.

Sagala, Syaiful. (2006) Administrasi Pendidikan Kontemporer. Bandung: Alfabeta.

Sambas Ali Muhidin \& Maman Abdurahman. (2007) Analisis Korelasi Regresi dan Jalur. Bandung: Pustaka Setia.

Sedarmayanti. (2010) Manajemen Sumber Daya Manusia, Reformasi Birokrasi, dan Manajemen Pegawai Negeri Sipil. Bandung: PT. Refika Aditama.

_. (2009). Sumber Daya Manusia dan Produktivitas Kerja. Bnadung: Mandar Maju

Sutrisno, Edy. (2010). Manajemen Sumber Daya Manusia, Jakarta: Kencana Prenada Media.

Schermerhorn, John R, James G. Hunt, Richards N. Osborn, (2001). Managing Organizatiional Behaviour, Australia: John Wiley \& Sons.Ltd.

Uno, Hamzah. (2008). Teori Motivasi \& Pengukurannya. Jakarta: Bumi Aksara. Usman,

Wagner \& Hollenbeck, (2010). Organizational Behaviour: Securing Competitive Advantege, New York, Routledge. 